A N N A L E S

UNIVERSITATIS MARIAE CURIE-SKŁODOWSKA LUBLIN - POLONIA

VOL. LXX, z. 1

SECTIO B

2015

Wydział Nauk o Ziemi i Gospodarki Przestrzennej UMCS, al. Kraśnicka 2cd, 20-718 Lublin, malgorzata.flaga@umcs.pl,przemyslaw.mroczek@umcs.pl

MAŁGORZATA FLAGA, PRZEMYSŁAW MROCZEK

\title{
Kongres Geografów Polskich „Granice Geografii” (17-21 czerwca 2015 r.) na Wydziale Nauk o Ziemi i Gospodarki Przestrzennej UMCS w Lublinie
}

W dniach 17-21 czerwca 2015 r. na Wydziale Nauk o Ziemi i Gospodarki Przestrzennej UMCS w Lublinie miał miejsce Kongres Geografów Polskich pod hasłem „Granice Geografii”. Była to impreza naukowa organizowana przez Wydział wraz z Komitetem Nauk Geograficznych PAN oraz Polskim Towarzystwem Geograficznym. Kongres posiadał szczególny wymiar, ponieważ termin i miejsce jego organizacji zbiegły się z obchodami 70-lecia Geografii Lubelskiej, jubileuszowym LX Zjazdem Polskiego Towarzystwa Geograficznego oraz IX Forum Geografów Polskich.

Lubelskie spotkanie geografów rozpoczęło się w środę, 17 czerwca 2015 roku Sesją Jubileuszową z okazji 70-lecia lubelskiego ośrodka geograficznego. Jej pierwsza część odbyła się w nowo otwartym budynku UMCS Ecotech-Complex (ul. Głęboka 39) i poza uczestnikami Kongresu wzięli w niej udział liczni Goście z Lublina i Polski. Wśród nich znalazł się JM Rektor UMCS, prof. dr hab. Stanisław Michałowski, a także przedstawiciele władz państwowych i władz miasta, którzy objęli Kongres swoim Honorowym Patronatem. W sesji uczestniczyli także członkowie Senatu UMCS.

Uroczystości rozpoczęły się od nadania tytułu Honorowego Profesora UMCS Profesorowi dr hab. Andrzejowi Kostrzewskiemu, Przewodniczącemu Komitetu Nauk Geograficznych PAN, który wygłosił przy tej okazji okolicznościowy wykład. Następnie, JM Rektor UMCS wręczył medale „Amicis Universitatis Mariae Curie-Skłodowska" osobom, które poprzez swoją działalność przyczyniły się do rozwoju i promocji Uczelni, a także prowadziły z nią aktywną współpracę na 
polu naukowym i dydaktycznym. Medale otrzymali kolejno: prof. dr hab. Marian Harasimiuk, Prodziekan i Dziekan Wydziału Biologii i Nauk o Ziemi, Prorektor UMCS dwóch kadencji, a także Rektor UMCS dwóch kadencji; mgr Beata Sielewicz, Regionalny Dyrektor Ochrony Środowiska w Lublinie oraz mgr inż. Zdzisław Strupieniuk, Dyrektor Roztoczańskiego Parku Narodowego.

W kolejnej części sesji jubileuszowej, Dziekan Wydziału Nauk o Ziemi i Gospodarki Przestrzennej prof. dr hab. Radosław Dobrowolski dokonał uhonorowania wyróżnionych pracowników Wydziału dyplomem „Zasłużony dla Wydziału Nauk o Ziemi i Gospodarki Przestrzennej”. Tytuł ten otrzymało 15 osób: prof. dr hab. J. Buraczyński, prof. dr hab. M. Harasimiuk, prof. dr hab. Z. Michalczyk, prof. dr hab. K. Wojciechowski, prof. dr hab. B. M. Kaszewski, prof. dr hab. M. Łanczont, prof. dr hab. R. Dębicki, prof. dr hab. A. Świeca, prof. dr hab. K. Pękala, prof. dr hab. J. E. Mojski, prof. dr hab. W. Warakomski, dr hab. K. Warakomska, dr K. Harasimiuk, dr E. Kardaszewska oraz dr L. Barwińska. Do grona osób wyróżnionych podczas tej części sesji jubileuszowej zaliczyć należy także wszystkich po kolei wymienionych emerytowanych pracowników Wydziału, którzy indywidualne z rąk Dziekana prof. R Dobrowolskiego otrzymali stosowne podziękowania wraz z egzemplarzem monografii „,70 lat ośrodka geograficznego w Uniwersytecie Marii Curie-Skłodowskiej", świeżo wydanej pod redakcją E. Skowronek, E. Kardaszewskiej i M. Flagi. Podsumowaniem 70 lat działalności lubelskiej geografii były dwie prezentacje przedstawione kolejno przez dr Krystynę Harasimiuk i prof. dr. hab. Radosława Dobrowolskiego, mówiące o lwowskich korzeniach lubelskiego ośrodka geograficznego oraz o jego powojennej historii i rozwoju. Uwieńczeniem pierwszej części sesji jubileuszowej był koncert pt. „Specjalista od wzruszeń”, wykonany przez Piotra Selima, muzyka związanego z Lubelską Federacją Bardów, który spotkał się z niezwykle ciepłym przyjęciem.

Druga część sesji jubileuszowej miała miejsce w budynku Wydziału Nauk o Ziemi i Gospodarki Przestrzennej przy al. Kraśnickiej 2cd. W jej trakcie, nastąpiło uroczyste odsłonięcie tablic pamiątkowych poświęconych najwybitniejszym twórcom lubelskiego ośrodka geograficznego. Następnie odbył się wernisaż „70 lat lubelskiego ośrodka geograficznego", koordynowany przez dr hab. Ewę Skowronek i dra hab. Sławomira Terpiłowskiego, prof. UMCS wraz z zespołem. Wystawę utworzyły plakaty prezentujące historię i osiągnięcia Wydziału, najważniejsze publikacje oraz specjalistyczny sprzęt, którym w przeszłości posługiwali się geografowie podczas badań terenowych.

Uroczyste otwarcie Kongresu Geografów Polskich nastąpiło w czwartek, 18 czerwca przy udziale władz Uczelni oraz zaproszonych Gości. Miejscem obrad ponownie była aula w nowo otwartym budynku Ecotech-Complex. Powitania wszystkich uczestników spotkania dokonał Dziekan Wydziału NoZiGP 
prof. dr hab. Radosław Dobrowolski, po czym nastąpiło odczytanie okolicznościowych adresów skierowanych na jego ręce.

Kolejna część uroczystości była poświęcona odznaczeniom osób zasłużonych dla geografii i wykazującym na tym polu szczególne osiągnięcia. Przewodniczący Prezydium Zarządu Głównego Polskiego Towarzystwa Geograficznego, prof. dr hab. Antoni Jackowski nadał tytuł Członka Honorowego PTG Profesorom: Jackowi Jani, Andrzejowi Lisowskiemu, Janowi Olędzkiemu oraz Eugeniuszowi Rydzowi. Następnie, wręczył Medal PTG Profesorowi Andrzejowi Ciołkoszowi. Ponadto nagrodzono cztery osoby, wyróżnione w konkursie na najlepszą pracę magisterską z zakresu geografii, organizowanym co roku przez Zarząd Główny PTG. Z kolei prof. dr hab. Andrzej Suliborski przedstawił laureatów konkursu Komitetu Nauk Geograficznych PAN na najlepszą pracę doktorską w zakresie geografii. Po krótkiej przerwie rozpoczęła się sesja plenarna, w której wygłoszono cztery referaty zamawiane, odnoszące się do współczesnych problemów oraz perspektyw rozwoju geografii jako dyscypliny naukowej. Zakończeniem sesji plenarnej były wystąpienia wspomnianych laureatów konkursu KNG, którzy zaprezentowali najważniejsze założenia i wyniki swoich rozpraw doktorskich.

Czwartkowa, popołudniowa część Kongresu miała odmienny charakter. Była to sesja terenowa poświęcona w głównej mierze wielokulturowemu dziedzictwu Lublina, ale uwzględniająca także środowisko przyrodnicze oraz gospodarcze oblicze miasta. Trasa sesji prowadziła przez momenty szczególnie ważne z punktu widzenia historii i kultury Lublina: poczynając od Wzgórza Czwartek, poprzez Katedrę Prawosławną Przemienienia Pańskiego, Wzgórze Zamkowe z Kaplicą Świętej Trójcy, aż po Stare Miasto oraz Archikatedrę Lubelską. Uwieńczeniem wycieczki po Lublinie była wizyta w murach Klasztoru Dominikanów na Starym Mieście, gdzie na klasztornym patio uczestnicy Kongresu kontynuowali naukowe i pozanaukowe dyskusje podczas uroczystej integracyjnej kolacji.

Na drugi dzień Kongresu, piątek 19 czerwca złożyły się przedpołudniowe obrady w trzech sesjach referatowych oraz popołudniowy panel dyskusyjny. Jednocześnie, w piątek miało także miejsce otwarcie wystawy zorganizowanej przez Zakład Kartografii i Geomatyki Wydziału NoZiGP pt. „Lubelszczyzna na mapach dawnych". Wystawa stanowiła wydarzenie towarzyszące Kongresowi, wpisując się w nurt imprez przygotowanych w ramach obchodów Międzynarodowego Roku Mapy.

Sesje były prowadzone w 11 sekcjach tematycznych, których tytuły nawiązywały do hasła przewodniego Kongresu. Ogółem wygłoszono blisko 100 referatów, którym przysłuchiwało się ponad 150 uczestników Kongresu, reprezentujących różne dyscypliny badawcze. Ponadto, przeprowadzona została sesja posterowa, w której zaprezentowano 26 posterów ukazujących szerokie spektrum zagadnień geograficznych. 
Ostatnim elementem debatowym Kongresu był panel dyskusyjny pt. „Granice geografii a jej perspektywy rozwojowe", który odbył się w godzinach popołudniowych w Inkubatorze Medialno-Artystycznym UMCS. W 2-godzinnej dyspucie, prowadzonej przez dra Wojciecha Janickiego oraz pięciu panelistów, geografów pochodzących z różnych polskich ośrodków naukowo-badawczych. Odpowiadając na pytania prowadzącego oraz licznie zgromadzonych słuchaczy, wyrazili oni swoje opinie na temat współczesnego stanu polskiej geografii i, w tym kontekście, dalszych ścieżek rozwoju i przemian, jakimi powinna ona podążać w przyszłości.

Podczas dwóch ostatnich dni Kongresu (20-21 lipca br.), tradycyjnie już dla zjazdów geografów odbyły się sesje terenowe, wiodące szlakami regionu lubelskiego. Jednodniowa wycieczka w dniu 20 czerwca (sobota), kierowana przez dra Przemysława Mroczka prowadziła przez Wyżynę Wołyńską, prezentując jej zachodnie mezoregiony: Grzędę Horodelską, Kotlinę Hrubieszowską i Grzędę Sokalską. Zagadnienia naukowe przedstawiane na trasie dotyczyły unikatowych miejsc i obiektów przyrodniczych i kulturowych pogranicza polsko-ukraińskiego. Trasa sesji obejmowała m. in. takie punkty, jak: Hrubieszów - wielokulturowe miasto Stanisława Staszica, Gródek nad Bugiem (tzw. Wołyń) - grodzisko, jeden z grodów czerwieńskich, Masłomęcz - zrekonstruowaną wioskę Gotów, Czermno - grodzisko, dawną stolicę grodów czerwieńskich, obecnie unikatowe stanowisko archeologiczne, jak również Turkowice - wieś znaną z przedwojennego żeńskiego prawosławnego monasteru i otoczonej kultem ikony Matki Bożej Turkowickiej.

$\mathrm{Z}$ kolei 2-dniowa sesja terenowa w dniach 20-21 czerwca (sobota-niedziela), pod kierownictwem dra Krzysztofa Kałamuckiego, była realizowana w północnej części Kotliny Sandomierskiej. Trasa wycieczki umożliwiła poznanie regionu w kontekście jego pogranicznego położenia, zarówno w odniesieniu do przebiegu jednostek geologicznych i geomorfologicznych, krain geobotanicznych i ekosystemów, jak i granic administracyjnych oraz historyczno-kulturowych. Podczas sesji zwiedzano następujące miejsca: Łysaków - kamieniołom i punkt widokowy, Łążek Garncarski - centrum garncarstwa, Janów Lubelski - centrum kulturalne i turystyczne regionu, Momoty - wieś w Lasach Janowskich, enklawę osadniczą, Ulanów - centrum flisactwa oraz Stalową Wolę - miasto będące ważnym ośrodkiem COP. Dodatkową atrakcją podczas wycieczki był spacer w rezerwacie przyrody „Imielty Ług”, znajdujący się na terenie Parku Krajobrazowego Lasy Janowskie oraz spływ kajakowy rzeką Bukową, która w przeszłości na pewnym odcinku stanowiła granicę zaboru rosyjskiego i austriackiego.

Zorganizowany w Lublinie Kongres Geografów był niewątpliwie ważnym wydarzeniem w kalendarium polskiej geografii. Zgodnie z zamierzeniem inicjatorów, umożliwił spotkanie przedstawicieli ośrodków geograficznych z całej Polski i dał kolejną okazję do dyskusji nad kondycją współczesnej polskiej geografii, zarysowującymi się nowymi polami badawczymi oraz możliwościami aplikacji i komercjalizacji wiedzy geograficznej. Kongres stworzył również sposobność do 


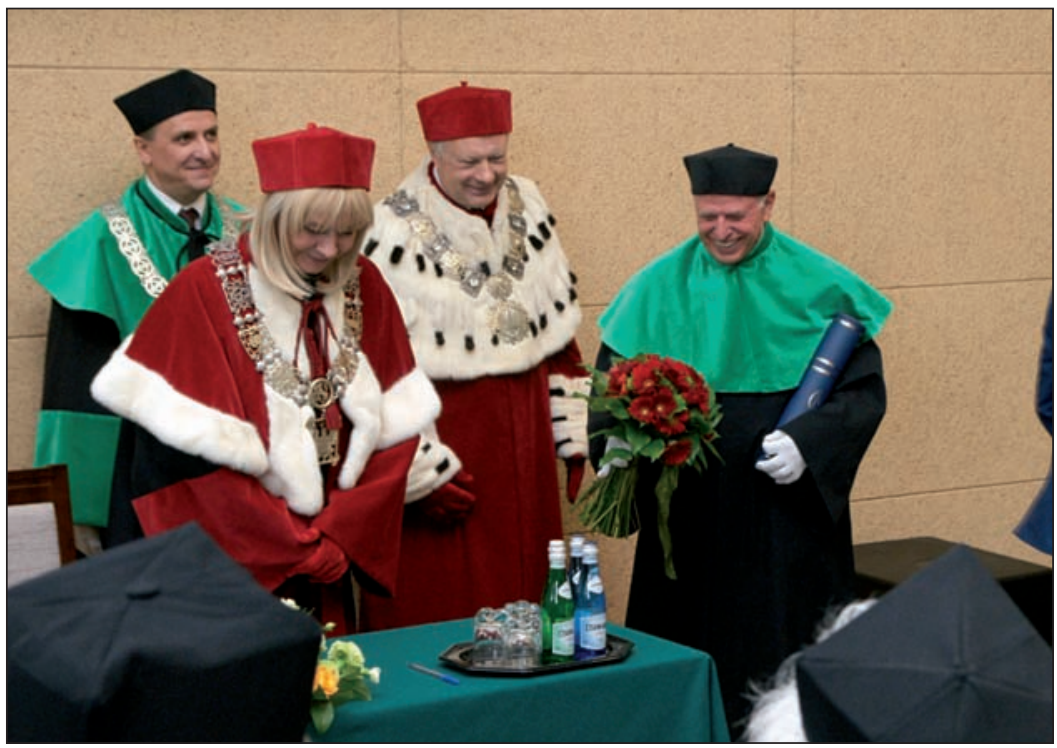

Fot. 1: Honorowy Profesor UMCS prof. dr hab. Andrzej Kostrzewski wraz z JM Rektorem UMCS prof. dr hab. S. Michałowskim, Prorektor ds. Studenckich prof. sztuk muz. Urszulą Bobryk oraz Dziekanem Wydziału Nauk o Ziemi i Gospodarki Przestrzennej prof. dr hab. Radosławem Dobrowolskim (fot. P. Cebrykow)

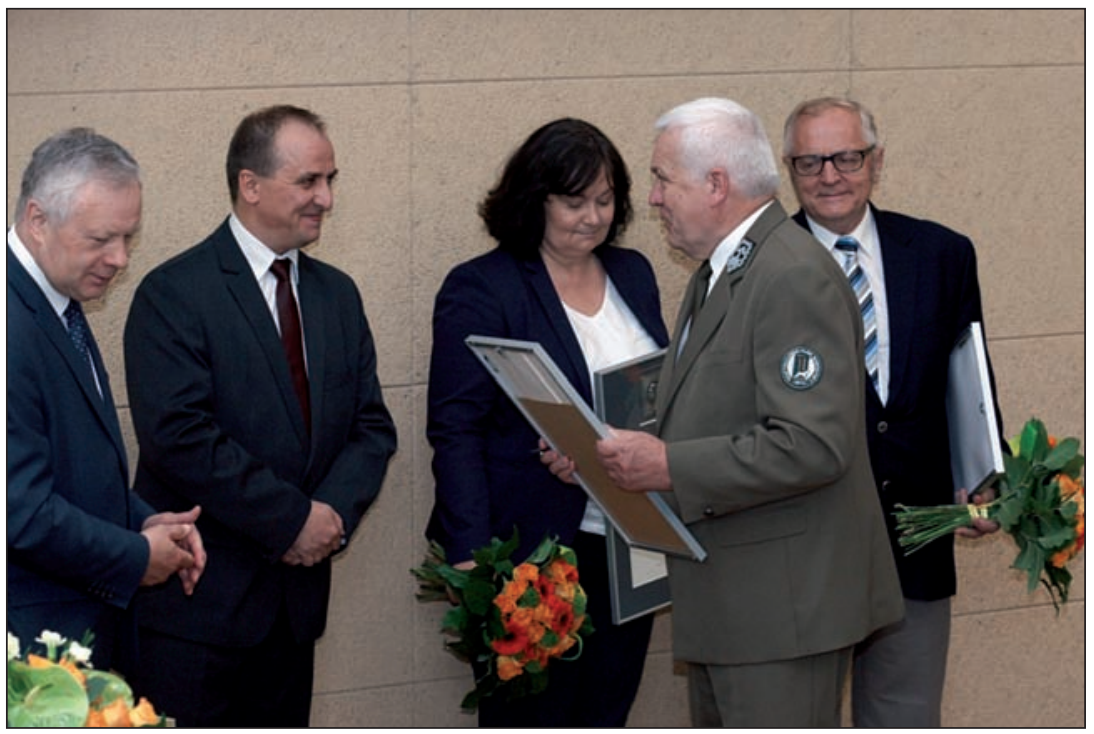

Fot. 2. JM Rektor UMCS prof. dr hab. S. Michałowski i dziekan WNoZiGP UMCS prof. dr hab. Radosław Dobrowolski wraz osobami wyróżnionymi medalem „Amicis Universitatis Mariae Curie-Skłodowska", od lewej: mgr Beata Sielewicz (Regionalny Dyrektor Ochrony Środowiska w Lublinie), mgr inż. Zdzisław Strupieniuk (Dyrektor Roztoczańskiego Parku Narodowego) i prof. dr hab. Marian Harasimiuk (WNoZiGP UMCS) (fot. P. Cebrykow) 


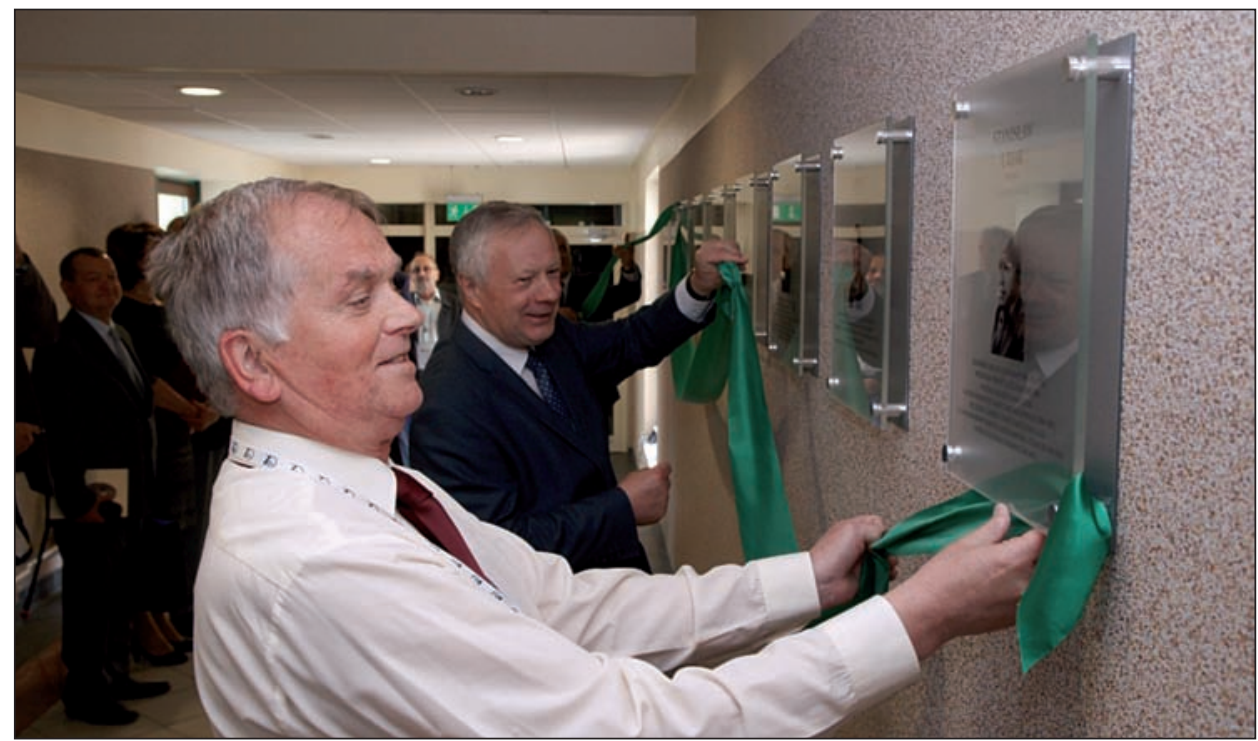

Fot. 3. Odsłonięcie tablic pamiątkowych poświęconych najwybitniejszym twórcom lubelskiego ośrodka geograficznego w budynku Wydziału NoZiGP przy al. Kraśnickiej 2cd w Lublinie. Na pierwszym planie prof. dr hab. Zdzisław Michalczyk oraz JM Rektor UMCS prof. dr hab. Stanisław Michałowski (fot. P. Cebrykow)

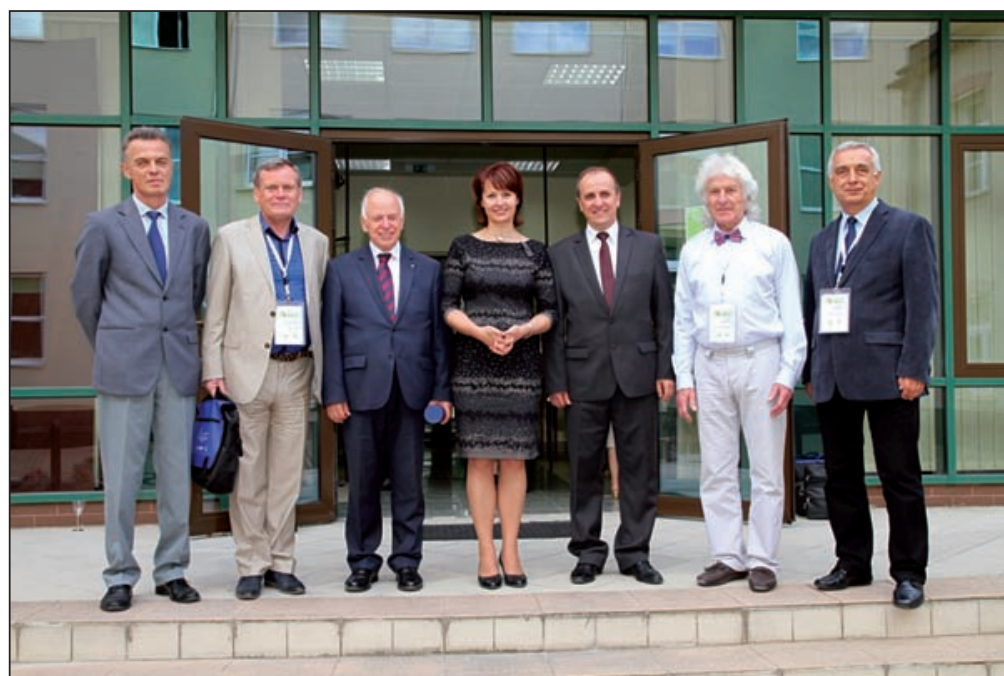

Fot. 4. Władze Wydziału NoZiGP UMCS w otoczeniu zaproszonych gości podczas otwarcia wystawy „70 lat lubelskiego ośrodka geograficznego”, od lewej: dr hab. Sławomir Terpiłowski, prof. UMCS (Prodziekan ds. Badań Naukowych), prof. dr hab. Leon Andrzejewski (Uniwersytet Gdański), prof. dr hab. Andrzej Kostrzewski (Uniwersytet im. Adama Mickiewicza w Poznaniu), dr Jolanta Rodzoś (Prodziekan ds. Studenckich), prof. dr hab. Radosław Dobrowolski (Dziekan Wydziału), prof. dr hab. Andrzej Bogucki (Uniwersytet im. I. Franko we Lwowie) i prof. dr hab. Kazimierz Krzemień (Uniwersytet Jagielloński w Krakowie) (fot. P. Zieliński) 

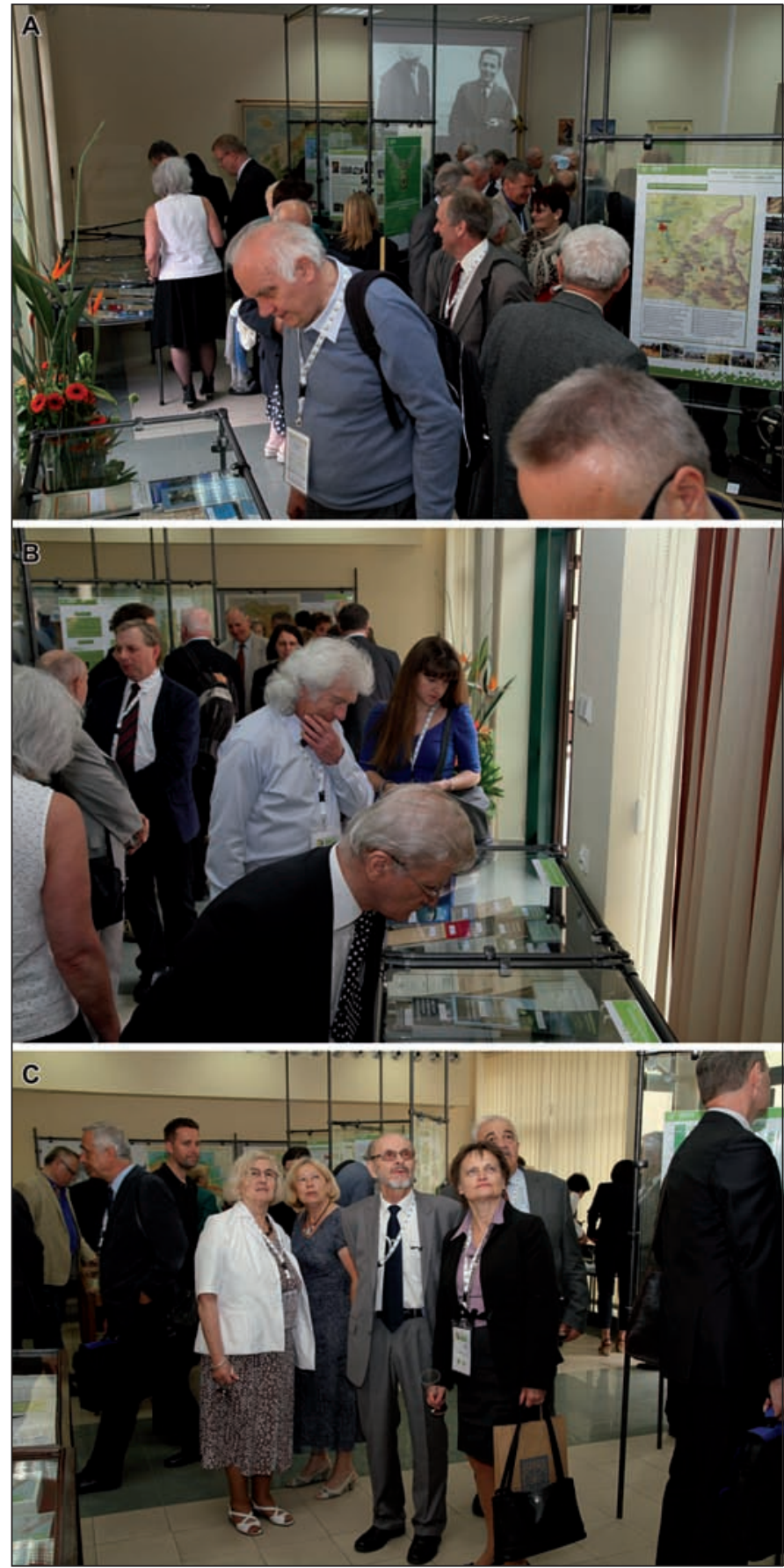

Fot. 5. Uczestnicy Kongresu zwiedzający wystawę „70 lat lubelskiego ośrodka geograficznego” (fot. P. Zieliński) 
zaprezentowania lubelskiego ośrodka geograficznego: jego wybitnych twórców i pracowników oraz bogatego dorobku naukowego, jaki powstał tutaj w trakcie 70 lat działalności. Dodatkowo, Kongres dał możliwość promocji Lublina i regionu lubelskiego poprzez przybliżenie szczególnie interesujących lokalnych walorów przyrodniczych i kulturowych.

$\mathrm{Na}$ stronie internetowej Kongresu (http://www.ptg2015.umcs.lublin.pl) dostępny jest zbiór materiałów prezentowanych w poszczególnych sesjach naukowych, do których zaliczają się pliki abstraktów wygłoszonych referatów i posterów, prezentacje wystąpień zaproszonych gości oraz artykuły składające się na tom specjalny „Czasopisma Geograficznego”. Ich dopełnieniem jest bogaty materiał fotograficzny, dokumentujący poszczególne wydarzenia mające miejsce podczas Kongresu, jak też w czasie sesji terenowych. 